\title{
Effect of Organic Manure and Biofertilizers on Plant Growth, Yield and Quality of Sweet Orange (Citrus sinensis L.)
}

\author{
Hemant Rana, Kirti Sharma* and Manju Negi \\ Department of Fruit Science, College of Horticulture, VCSG UUHF, \\ Bharsar, Pauri Garhwal, Uttarakhand (263145), India \\ *Corresponding author
}

\section{A B S T R A C T}

The present investigation Effect of organic manure and biofertilizers on plant growth, yield and quality of sweet orange (Citrus sinensis L.) cv. Mosambi was

\section{Keywords}

Farm yard manure, Biofertilizers, Citrus, Yield and Quality.

\section{Article Info}

Accepted:

15 March 2020

Available Online:

10 April 2020 conducted at fruit orchard Department of Fruit Science, College of Horticulture, VCSG Uttarakhand University of Horticulture and Forestry, Bharsar, Pauri Garhwal during the year 2017-18. The experiment was conducted to find out the most suitable treatment combination of FYM and biofertilizers for better yield, quality of citrus fruits. The experiment was laid out according to Randomized Complete Block Design with eight treatments and three replications. Based on the results obtained from the present investigations, it was observed that the maximum increase in plant height, plant volume, trunk girth, leaf size, no of flowers/ plant, fruit setting, average fruit weight, fruit yield/ plant, fruit length, fruit diameter, were observed maximum with treatment $\mathrm{T}_{8}$ FYM (40 kg/ plant) + VAM (100 g/ plant $)+$ Azotobacter $(10 \mathrm{~g} / \mathrm{plant})$. While maximum value of quality parameters like Juice percentage, TSS, Titrable acidity, Ascorbic acid and total sugar were observed in treatment $\mathrm{T}_{6}$ FYM (40 kg/ plant) + Azotobacter $(10 \mathrm{~g} / \mathrm{plant})$.

\section{Introduction}

Citrus is one of the important fruit among all the fruit crops. It belongs to family Rutaceae and it is native to china. The total production of citrus fruits in world is 139.80 million tones from an area of 9.08 million hectare, in which India is in third position in production of citrus followed by China (35.47 million tones) and Brazil (19.07 million tones). The total production of citrus fruits in
India is 11.15 million tones from an area of 1.02 million hectare (Horticulture Statistics 2016-17).

Citrus fruit is third largest fruit in cultivation which shares $12.5 \%$ production among all the fruit crops in India. In citrus group, major citrus species are mandarin (Citrus reticulate), sweet orange (Citrus sinensis), lime (Citrus aurantifolia), lemon (Citrus lemon) and grapefruit (Citrus paradise). 
Nutrition in citrus plays an important role for maintaining vigour, productivity and quality fruit production for longer period. Improper and inadequate nutrition is one of the major causes of citrus decline in India (Chadha et $a l ., 1970)$. The response of fertilization in improving the growth, yield and fruit quality different citrus fruits is well recognized under different agro climatic regions of the country (Ram et al., 1997). Organic manure contains plant nutrients in small quantities as compared to fertilizers but they influence in building up of organic matter, good soil aggregation, permeability of soil and related physical properties to long lasting supply of several macro and micronutrients, vital plant promoting substances apart from increasing the density of microbes in the soil.

This helps in the maintenance and possible improvement of soil fertility and health for sustaining crop productivity. . FYM are source of primary nutrients of plants which contain $0.5 \% \mathrm{~N}_{2} \mathrm{O}, 0.2 \% \mathrm{P}_{2} \mathrm{O}_{5}$ and $0.5 \% \mathrm{~K}_{2} \mathrm{O}$. Nitrogen is essential component of amino acids, protein, nucleic acid, enzymes and alkaloids. Biofertilizers as a better supplement can improve the quality and yield of fruit crops.

Microbial inoculants especially the VAM inoculation to the fruit plants enhance the possibility of curtailing about 50 per cent $\mathrm{P}$ fertilizers without reducing the yield of crop. Nitrogen fixing biofertilizers mainly Azospirillum and Azotobacter able to fix 20$40 \mathrm{~kg} \mathrm{~N} /$ ha and produce growth promoting substances (Hazarika and Ansari, 2007). Use of microbial inoculants is not only a low cost technology but also it takes adequate care of soil health and environmental safety. Biofertilizers are able to fix atmospheric nitrogen in the range of 20- $200 \mathrm{~kg} \mathrm{ha}^{-1}$ year $^{-1}$, solubilize $\mathrm{P}$ in the range of $30-50 \mathrm{~kg}$ ha $^{-1}$ year $^{-1}$, mobilize $\mathrm{P}, \mathrm{Zn}, \mathrm{Fe}$, Mo to varying extent (Hazarika and Ansari, 2007).

\section{Materials and Methods}

The experiment was conducted at the Fruit Block, College of Horticulture, VCSG UUHF, Bharsar during the month of December 2017 to March 2018. The maximum temperature during May - June is recorded between $21^{\circ} \mathrm{C}-24^{\circ} \mathrm{C}$ and nights are cool. December and January are the coldest months, the minimum temperature reaches from $1^{\circ} \mathrm{C}$ to $6^{\circ} \mathrm{C}$. Relative humidity is normally highest during rainy season (JulyAugust), often recorded near to saturation point (90-96\%).

Minimum and maximum rainfall was received during the month of July 2017 (234.95 mm) and August $2017(182 \mathrm{~mm})$ respectively. The minimum and maximum temperature was recorded during January $2017\left(5.12{ }^{\circ} \mathrm{C}\right)$ and June $2017 \quad\left(24.69{ }^{\circ} \mathrm{C}\right)$ respectively. The experiment was conducted under Randomized Complete Block Design with eight treatments with three replications. viz., $\mathrm{T}_{1}$ : control, $\mathrm{T}_{2}$ : FYM $40 \mathrm{~kg} /$ plant (RDF), T 3 : VAM (100 g/ plant), $\mathrm{T}_{4}$ : Azotobacter (10 g/ plant), $\mathrm{T}_{5}: \mathrm{FYM}$ (40 kg/ plant) + VAM(100 g/ plant), T6: FYM (40 kg/ plant) + Azotobacter (100 g/ plant), $\mathrm{T}_{7}$ : VAM (100 g/ plant $)+$ Azotobacter $(100 \mathrm{~g} /$ plant) and $\mathrm{T}_{8}$ : FYM (40 kg/ plant) + VAM $(100 \mathrm{~g} /$ plant $)+$ Azotobacter $(10 \mathrm{~g} /$ plant $)$.

The required quantity of organic manure were applied during second week of March along with VAM and Azotobacter by broadcasting under the periphery of trees that is $30 \mathrm{~cm}$ away from the trunk and were mixed with soil. One week prior to application, VAM and FYM were mixed thoroughly and covered with gunny bags. For the treatment which involve the seldom application of biofertilizers, including single biofertilizers $\left(\mathrm{T}_{3}\right.$ and $\left.\mathrm{T}_{4}\right)$ and multiple biofertilizers $\left(\mathrm{T}_{7}\right)$, media were prepared by dissolving jiggery in mild hot water, for inoculation and let cooled. 
These medias are used to inoculation the biofertilizers through mixing and applied directly to the soil around the trunk and observations were recorded on Increase in plant height $(\mathrm{cm})$, Plant volume $\left(\mathrm{m}^{3}\right)$, Trunk growth $(\mathrm{cm})$, Leaf area $\left(\mathrm{cm}^{2}\right)$, Number of flowers/ plant, Fruit setting (\%),Fruit yield (kg/ plant), Average fruit weight (g), Fruit length $(\mathrm{cm})$, Fruit diameter $(\mathrm{cm})$, Juice per cent, Total soluble solids, Titrable acidity (\%),Ascorbic acid content (mg/ 100g) and Total Sugars (\%).

\section{Results and Discussion}

\section{Effect of organic manure and biofertilizers on growth characters}

The plant characteristics like increase in plant height $(25.23 \mathrm{~cm})$, trunk girth $(0.97 \mathrm{~cm})$, plant volume $\left(4.87 \mathrm{~m}^{3}\right)$ and leaf area $\left(40.54 \mathrm{~cm}^{2}\right)$ were significantly influence due to the application organic manure and biofertilizers. The maximum values of these parameters were recorded in the treatment $\mathrm{T}_{8}(\mathrm{FYM}+$ Azotobacter + VAM. It could be occurs due to the availability of required quantity of all nutrients in these treatments and organic manure and biofertilizers which improved soil conditions which becomes favorable for increasing the growth characteristics of plant.

Khehra and Bal (2014) also reported that plant height increase significantly by biofertilization with Azotobacter in combination with FYM. According to Khehra and Bal (2014) increase in height might be due to the fact that nitrogen as fixed by Azotobacter and being a constituent of protein and chlorophyll, plays a vital role in photosynthesis. It enhances accumulation of carbohydrates which, in turn, increase the growth of the plants and the increase in trunk diameter could be attributed to the stimulatory activity of microflora in the rhizosphere leading to increased nutrient availability and hence vigorous plant growth. Better vegetative growth with various biofertilizers treatments could be due to better availability of nutrients and their effective utilization by the plants. With inoculation of biofertilizers plant volume increases significantly due to increased cell metabolism as result of increase enzymatic activity, chlorophyll content and photosynthetic processes (Table 1).

\section{Effect of organic manure and biofertilizers on flowering and fruiting characters}

The flowering characteristics in terms of number of flowers/plant (98.33) and fruit setting $(66.15 \%)$ were significantly influenced due to the application of organic manure with combination of biofertilizers. The maximum number of flowers/ plant and fruit setting (\%) were recorded with the treatment $\mathrm{T}_{8}(\mathrm{FYM}+$ Azotobacter + VAM).

There was increase in photosynthetic activity, transport of photosynthetic product and production of endogenous growth regulatory substances through the application of biofertilizers. During the fruit development phase, fruit drop occurs at various stages due to abscissic acid layer development near the end of stalk of fruit and this layer formation is inhibited by the biofertilizers application (Prabhu et al., 2018).

According to Marathe \& Bharambe (2007) there are increase in nutrient availability from FYM, organic phosphorus through VAM and IAA from Azotobacter which may have increased various endogenous hormonal levels in plant tissue which might be responsible for enhancing flowering and fruit setting.

The maximum average fruit weight (104.02 g) and fruit yield $(5.89 \mathrm{~kg} /$ plant $)$ were also recorded with the treatment $\mathrm{T}_{8}(\mathrm{FYM}+$ Azotobacter + VAM). The maximum yield was obtained by the application of biofertilizers and organic manure which is the 
result of increasing the soil nutrient status, soil physical properties, soil health and their uptake by the plants.

Same treatment also have maximum vegetative growth in terms of plant height, plant volume and leaf size which have produced the higher quantum of carbohydrates needed for the development of the fruits thereby, increasing the number, size and weight of fruits which ultimately leads towards getting higher yield in these treatments.

According to Singh and Varu (2013), the application of organic manure with major nutrients helped for increasing the available major nutrients as well as other essential nutrients and higher nutrient content and metabolic level enhance the growth parameter, ultimately leading to higher yield. The application of biofertilizers with manure might have increase the total chlorophyll content which in turn increased the photosynthesis and ultimately improved fruit yield (Table 2).

\section{Effect of organic manure and biofertilizers on physical characteristics of fruit}

Present findings indicate that Physical characteristics of fruits were markedly improved by application of organic manure and biofertilizers during the period of study. Result showed that maximum fruit length $(6.19 \mathrm{~cm})$ and maximum fruit diameter $(6.87$ $\mathrm{cm})$ were recorded with the treatment $\mathrm{T}_{8}$ (FYM + Azotobacter + VAM). It could be occur due to balanced availability of nutrients and growth promoting hormones which are produced by biofertilizers. This may be attributed to better fillings of fruits due to more balanced uptake of nutrients which may have lead to better metabolic activities in the plant ultimately lead to high protein and carbohydrate synthesis. Similar results were also observed by Ram and Rajput (2004).

There was increase in average fruit weight due to the integration of organic and biofertilizers sources of nutrients which accelerated mobility of photosynthates from source to sink as influenced by the growth hormones and these hormones were released or synthesized due to organic sources of nutrients. The increase in fruit volume was attributed to the corresponding increase in length and diameter (Bhandari et al., 2018) (Table 3).

\section{Effect of organic manure and biofertilizers on chemical characteristics of fruit}

The influence of different treatments also showed significant differences in biochemical attributes of sweet orange fruits. The fruit quality parameters in terms of juice \%, TSS, ascorbic acid, total sugars were significantly enhanced by organic manure and biofertilizers application. The increase in quality components observed in FYM along with biofertilizers may be due to the fact that Azotobacter provides nitrogen to the plant beside, it provides growth promoting substances viz., Indole acetic acid (IAA), Gibberlic acid (GA), vitamin B and some antifungal substances.

The enhance uptake of nutrient, ammonium, phosphate, potassium and iron, improve water status and increase nitrate reductase activity in the plants. Azotobacter excretes ammonia in the rhizosphere in presence of root exudates, which help in the nutrient uptake by the roots. Similar results were also observed by Patel et al., (2005). Ram and Rajput (2000) also reported improvement in fruit quality parameters with application of organic manures and biofertilizers. 
Table.1 Effect of organic manure and biofertilizers on increase in plant height, plant volume, Trunk girth $(\mathrm{cm})$ and leaf size $\left(\mathrm{cm}^{2}\right)$ of sweet orange cv. Mosambi

\begin{tabular}{|c|c|c|c|c|}
\hline Treatment & $\begin{array}{c}\text { Increase in plant } \\
\text { height } \mathbf{( c m )}\end{array}$ & $\begin{array}{c}\text { Plant volume } \\
\left(\mathbf{m}^{\mathbf{3}}\right)\end{array}$ & $\begin{array}{c}\text { Trunk girth } \\
(\mathbf{c m})\end{array}$ & Leaf size $\left.\mathbf{( c m}^{\mathbf{2}}\right)$ \\
\hline $\mathbf{T}_{\mathbf{1}}$ & 13.17 & 3.16 & 0.33 & 22.47 \\
\hline $\mathbf{T}_{\mathbf{2}}$ & 20.37 & 4.27 & 0.60 & 35.20 \\
\hline $\mathbf{T}_{\mathbf{3}}$ & 15.47 & 3.41 & 0.40 & 25.51 \\
\hline $\mathbf{T}_{\mathbf{4}}$ & 16.13 & 3.42 & 0.43 & 27.48 \\
\hline $\mathbf{T}_{\mathbf{5}}$ & 23.60 & 4.66 & 0.67 & 38.51 \\
\hline $\mathbf{T}_{\mathbf{6}}$ & 24.13 & 4.70 & 0.77 & 39.26 \\
\hline $\mathbf{T}_{\mathbf{7}}$ & 19.63 & 3.78 & 0.53 & 32.62 \\
\hline $\mathbf{T}_{\mathbf{8}}$ & 25.23 & 4.87 & 0.97 & $40.54^{*}$ \\
\hline S. E.(d) & 0.66 & 0.47 & 0.12 & 1.18 \\
\hline C.D.0.05 & 1.43 & 1.02 & 0.26 & 2.25 \\
\hline
\end{tabular}

Table.2 Effect of organic manure and biofertilizers on number of flower/ plant, fruit set (\%), average fruit weight $(\mathrm{g})$ and fruit yield $(\mathrm{kg})$ of sweet orange cv. Mosambi

\begin{tabular}{|c|c|c|c|c|}
\hline Treatment & $\begin{array}{c}\text { No of flowers/ } \\
\text { plant }\end{array}$ & Fruit setting\% & $\begin{array}{c}\text { Average fruit } \\
\text { weight }(\mathbf{g})\end{array}$ & $\begin{array}{c}\text { Fruit yield/ plant } \\
\text { (kg) }\end{array}$ \\
\hline $\mathbf{T}_{\mathbf{1}}$ & 47.67 & 47.53 & 77.26 & 1.59 \\
\hline $\mathbf{T}_{\mathbf{2}}$ & 65.67 & 55.38 & 93.32 & 3.38 \\
\hline $\mathbf{T}_{\mathbf{3}}$ & 47.33 & 51.29 & 84.07 & 1.93 \\
\hline $\mathbf{T}_{\mathbf{4}}$ & 49.67 & 51.64 & 81.31 & 1.98 \\
\hline $\mathbf{T}_{\mathbf{5}}$ & 94.33 & 63.95 & 98.42 & 5.29 \\
\hline $\mathbf{T}_{\mathbf{6}}$ & 84.33 & 55.83 & 97.63 & 4.52 \\
\hline $\mathbf{T}_{\mathbf{7}}$ & 62.67 & 47.87 & 84.13 & 2.92 \\
\hline $\mathbf{T}_{\mathbf{8}}$ & 98.33 & 66.15 & 104.02 & 5.89 \\
\hline S. E.(d) & 3.77 & 2.80 & 3.69 & 0.26 \\
\hline C.D. $\mathbf{. 0 . 0 5}$ & 8.16 & 6.07 & 8.00 & 0.57 \\
\hline
\end{tabular}

Table.3 Effect of organic manure and biofertilizers on Average fruit weight $(\mathrm{g})$, fruit length and fruit diameter of sweet orange cv. Mosambi

\begin{tabular}{|c|c|c|}
\hline Treatment & Fruit length $(\mathbf{c m})$ & Fruit diameter(cm) \\
\hline $\mathbf{T}_{\mathbf{1}}$ & 5.52 & 5.31 \\
\hline $\mathbf{T}_{\mathbf{2}}$ & 5.72 & 6.37 \\
\hline $\mathbf{T}_{\mathbf{3}}$ & 5.54 & 5.43 \\
\hline $\mathbf{T}_{\mathbf{4}}$ & 5.56 & 5.67 \\
\hline $\mathbf{T}_{\mathbf{5}}$ & 6.01 & 6.53 \\
\hline $\mathbf{T}_{\mathbf{6}}$ & 6.12 & 6.65 \\
\hline $\mathbf{T}_{\mathbf{7}}$ & 5.59 & 6.01 \\
\hline $\mathbf{T}_{\mathbf{8}}$ & 6.19 & 6.87 \\
\hline S. E.(d) & 0.22 & 0.12 \\
\hline C.D. $\mathbf{0 . 0 5}$ & 0.48 & 0.27 \\
\hline
\end{tabular}


Table.4 Effect of organic manure and biofertilizers on Juice (\%), TSS ( ${ }^{\circ}$ Brix), titrable acidity $(\%)$, ascorbic acid ( $\mathrm{mg} / 100 \mathrm{ml})$ and Total sugar $(\%)$ of fruit of sweet orange cv. Mosambi

\begin{tabular}{|c|c|c|c|c|c|}
\hline Treatment & Juice \% & TSS ( Brix) & $\begin{array}{c}\text { Titratable } \\
\text { acidity }(\%)\end{array}$ & $\begin{array}{c}\text { Ascorbic acid } \\
(\mathrm{mg} / 100 \mathrm{ml})\end{array}$ & $\begin{array}{c}\text { Total } \\
\text { sugar }(\%)\end{array}$ \\
\hline $\mathbf{T}_{1}$ & 11.46 & 8.90 & 0.40 & 41.92 & 5.86 \\
\hline $\mathbf{T}_{2}$ & 29.27 & 9.60 & 0.32 & 44.49 & 6.38 \\
\hline $\mathbf{T}_{\mathbf{3}}$ & 15.68 & 8.93 & 0.34 & 43.51 & 6.02 \\
\hline $\mathbf{T}_{4}$ & 13.41 & 9.03 & 0.33 & 43.14 & 6.04 \\
\hline $\mathbf{T}_{5}$ & 31.61 & 10.60 & 0.23 & 47.83 & 6.58 \\
\hline $\mathbf{T}_{6}$ & 30.07 & 10.83 & 0.21 & 48.66 & 6.79 \\
\hline $\mathbf{T}_{7}$ & 19.23 & 9.27 & 0.39 & 43.85 & 6.11 \\
\hline $\mathbf{T}_{8}$ & 33.53 & 10.47 & 0.32 & 47.03 & 6.48 \\
\hline S. E. (d) & 3.32 & 0.18 & 0.03 & 0.80 & 0.08 \\
\hline C.D.0.05 & 7.20 & 0.39 & 0.06 & 1.74 & 0.17 \\
\hline
\end{tabular}

The data indicated that, the maximum juice percentage $(33.53 \%)$ was recorded with the treatment $\mathrm{T}_{8}(\mathrm{FYM}+$ Azotobacter $+\mathrm{VAM})$. Bhandari et al., 2018 reported that addition of organic matter in soil, improves the soil structure, penetration, retention of moisture etc. and biofertilizers improves the root proliferation. Application of treatment $\mathrm{T}_{6}$ (FYM + Azotobacter) resulted in maximum total soluble solids (TSS) of sweet orange $\left(10.83^{\circ}\right.$ Brix) which was found statistically at par with $\mathrm{T}_{5}(\mathrm{FYM}+\mathrm{VAM})$ and $\mathrm{T}_{8}(\mathrm{FYM}+$ $\mathrm{VAM}+$ Azotobacter) and minimum titrable acidity $(0.21 \%)$ was occur in the treatment $\mathrm{T}_{6}$ $(\mathrm{FYM}+$ Azotobacter $)$ while maximum ascorbic acid (48.66 mg/ $100 \mathrm{ml})$ and total sugar $(5.86 \%)$ were also recorded with $\mathrm{T}_{6}$ (FYM + Azotobacter) (Table 4).

The improved fruit quality may be attributed to better vegetative growth of the treated plants, which resulted in higher quantities of photosynthates (starch, carbohydrate etc.) and translocation of photosynthates to the fruits thus increasing the contents of various fruits quality parameters (Dutta et al., 2014). Ram and Pathak (2007) reported that the fruit quality parameters, particularly TSS were improved with application of FYM.
According to Bhandari et al., (2018) FYM increased TSS and total sugars due to gradual supply of nutrients and organic manures throughout the growth period which increased the metabolites in improvement in soil moisture availability, soil $\mathrm{pH}$, organic carbon and nutrient status of the soil and decrease acidity of fruits may be attributed to their conversion into sugars and their derivatives by the reactions involving reversal of glycolytic pathway or might be used in respiration or both. Similar findings were also reported by Singh and Varu (2013), Dutta et al., (2010) and Yadav et al., (2007).

\section{References}

Bhandari J, Kanpure R N, Singh O P, Kachouli B and Patidar D K. 2018. Effect of organic and inorganic nutrient sources on growth, yield and quality of acid lime (Citrus aurantifolia Swingle). International Journal of Chemical Studies 6(1): 1635-1639.

Bhandari J, Kanpure R N, Singh O P, Kachouli B and Patidar D K. 2018. Effect of organic and inorganic nutrient sources on growth, yield and quality of acid lime (Citrus aurantifolia Swingle). 
International Journal of Chemical Studies 6(1): 1635-1639.

Chadha K L, Radhawa N S, Bindra O S, Chohan J S and Kohr L C. 1970. Citrus decline in India. Pub: PAU, USAID, Punjab, India.

Dutta P, Kundu S and Chatterjee S. 2010. Effect of biofertilizers on homestead fruit production of papaya cv. Ranchi. Acta Horticulture 851:385-388.

Dutta P, Kundu S and Chatterjee S. 2010. Effect of biofertilizers on homestead fruit production of papaya $\mathrm{cv}$. Ranchi. Acta Horticulture 851:385-388.

Hazarika B N and Ansari S. 2007. Biofertilizers in fruit crops - a review. Agriculture Revolution 28(1): 69-74.

Khehra S and Bal J S. 2014. Influence of organic and inorganic nutrient sources on growth of lemon (Citrus limon (L.) BURM.) cv. Baramasi. Journal of Experimental Biology and Agricultural Science 2(1): 126-129.

Marathe R A and Bharambe P R. 2007. Growth, yield and quality of sweet orange $\mathrm{cv}$. Mosambi in response to INM in vertisols of central India. Indian Journal of Horticulture. 64(3): 274-277. Prabhu M, Prathiban S K, Ramesh, Usha B, Rani and Vijayasamundeeswari A. 2018. Effect of integrated nutrient management on acid lime (Citrus aurantifolia. Swingle (L.). Indian Journal of Agricultural Research 52(3): 290-294

Ram R A and Rajput M S. 2000. Role of biofertilisers and manures in production of guava (Psidium guajava L.) cv. Allahabad Safeda. Haryana Journal of Horticultural Sciences; 29 (3/4):193194.

Ram L, Kohli R R, Srivastava A K, Huchche A D and Das H C.1997. Nutritional requirement of Nagpur mandarin (Citrus reticulate Blanco) grown on Vertisols in central region. Indian Journal of Horticulture 54: 91-97.

Ram R A and Pathak R K. 2007. Integration of organic farming practices for sustainable production of guava: a case study. Acta Horticulture 735: 357-364.

Singh J K and Varu D K. 2013. Effect of integrated nutrient management in papaya (Carica papaya) cv. Madhubindu. Asian Journal of Horticulture 8(2): 667-670.

Yadav R, Singh H K and Yadav A L. 2007. Effect of INM on plant growth and soil properties of aonla orchard under sodic soil condition. Plant Archives 7(2): 859-861.

\section{How to cite this article:}

Hemant Rana, Kirti Sharma and Manju Negi. 2020. Effect of Organic Manure and Biofertilizers on Plant Growth, Yield and Quality of Sweet Orange (Citrus sinensis L.). Int.J.Curr.Microbiol.App.Sci. 9(04): 2064-2070. doi: https://doi.org/10.20546/ijcmas.2020.904.247 